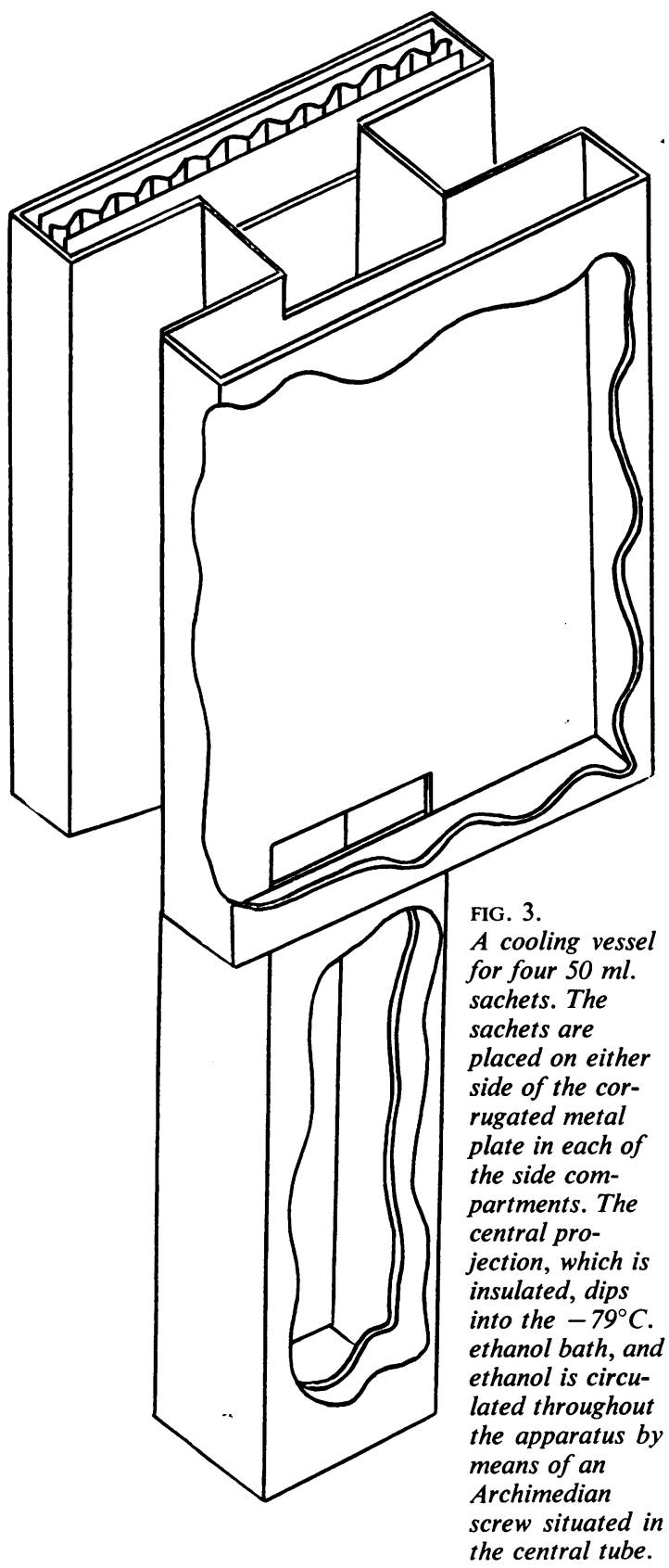

REFERENCES (cont.)

Polge, C., and Lovelock, J. E. (1952). Vet. Rec., 64, 396.

, Smith, A. U., and Parkes, A. S. (1949). Nature (Lond.), 164, 666.

Skeggs, L. T. (1960). Ann. N.Y. Acad. Sci., 87, 650.

Smith, A. U. (1954). In Biological Applications of Freezing and Drying, ed. R. J. C. Harris, p. 1. Academic Press, New York.

\section{Macroscopic demonstration of infarction in fresh brain slices}

\author{
D. N. RAINE From the General Hospital, \\ Newcastle-on-Tyne
}

The changes in the naked-eye appearance of gross sections of unfixed brain following cerebral infarction are often subtle. Although they rarely confuse the experienced observer, it is useful to be able to confirm their presence and demonstrate the extent of the infarcted areas at the time of necropsy. Associated with the many changes occurring in injured tissue, there is a striking fall in the hydrogen ion concentration, and this has been utilized to provide a visual demonstration of the infarcts.

\section{PROCEDURE}

The cut slices of brain are laid out in a dish and sufficient B.D.H. Universal indicator added to form a thin film over the surface. The plastic dropping bottles, in which $100 \mathrm{ml}$. of solution is supplied, are most convenient for this purpose. The cut surface of the brain is irregular, and the indicator tends to pool, but this does not interfere with the interpretation of any changes that may occur. Because the indicator is in aqueous solution and does not easily penetrate the brain tissue, two minutes should be allowed before any colour change is looked for. The colour of the indicator when added is deep green. On normal brain tissue it is a brighter yellow green indicative of a $p \mathrm{H}$ of 7. Areas of infarction show in sharp contrast as bright red, the $p \mathrm{H}$ of the tissue in these areas being less than 4 . The poor penetration of the dye into the brain tissue has the advantage that the indicator can be rinsed off, and blocks taken for histological examination without being affected by this prior treatment.

\section{LIMITATIONS}

There must be a minimum time between the occurrence of a vascular occlusion and the death of the patient for the $p \mathrm{H}$ change to occur. The duration of this period is not known, but it is believed to be short and probably of the order of an hour or two. On the other hand there will be a maximum time between the death of the patient and examination of the brain after which non-infarcted tissue will have degenerated to such an extent as to be indistinguishable by this method from areas of infarction. From the cases studied so far it can be stated that infarcts can still be demonstrated 36 hours after death but in a necropsy four days after death the whole of the brain tissue turned the indicator red.

I am indebted to Dr. B. E. Tomlinson, in whose department these studies were made, for his help and encouragement.

Received for publication 7 July 1962. 